"O olho do homem serve de fotografia ao invisivel, como o ouvido serve de eco ao silêncio."

Machado de Assis

"Sertão: estes teus vazios. O senhor vá. Alguma coisa ainda e contra.

Porque sertão é dentro da gente."

Guimarães Rosa

Neste número da Revista da Anpoll homenageamos dois grandes escritores da Literatura Brasileira: Machado de Assis e Guimarães Rosa. Em 2008, passaram-se cem anos da morte do nosso autor realista e do nascimento de João Guimarães Rosa: em 29 de setembro de 1908 faleceu Machado de Assis e, no dia 27 de junho do mesmo ano, nasceu Guimarães Rosa. Essa homenagem foi desdobrada em dois volumes devido à surpreendente quantidade de artigos recebidos de excelente qualidade, nos quais aspectos lingüísticos e literários das obras desses autores são abordados e analisados a partir de diferentes vertentes teóricas.

John Gledson, em sua obra Por um novo Machado de Assis, reafirma a importância de revelar "aos leitores um novo e diferente Machado de Assis" e os 
artigos aqui reunidos somam-se à extensa fortuna crítica do nosso escritor realista para revelar novos olhares sobre os romances e contos machadianos e desvendar novos aspectos sobre o cronista, o crítico e o dramaturgo Machado de Assis.

O mesmo pode ser dito a respeito de Guimarães Rosa, especialmente em 2006, edições comemorativas de Sagarana e Grande Sertão Veredas juntaram-se às publicações de livros que reuniram a correspondência passiva e ativa do autor mineiro com seus tradutores e, em 2007, a uma breve biografia sobre o autor. Essas publicações trouxeram novos elementos, nos quais os pesquisadores se detiveram para desvendar novas análises, estabelecer comparações e focar novos aspectos na obra de Rosa.

Os dois volumes deste número da Revista da Anpoll apresentam sessões de artigos, entrevistas e resenhas.

Compõem o volume I três sessões de ensaios, Machado de Assis romancista: metáforas, contradições e leituras; Machado de Assis: do esquecimento à fortuna crítica; e Os grandes lugares-comuns de Grande Sertão: veredas. Em entrevista inédita, John Gledson, autor de Machado de Assis: Ficção e História, Por um novo Machado de Assis, fala sobre a atualidade da obra machadiana, sobre seu novo livro e o impacto fora do Brasil de estudos realizados por estrangeiros, como os do próprio entrevistado, os de Helen Caldwell e de Jean-Michel Massa. O volume I encerra-se com uma resenha sobre a biografia Sinfonia Minas Gerais: a vida e a literatura de João Guimarães Rosa, de Alaor Barbosa.

Neste volume, há também três seções de ensaios, Machado de Assis: contos e crônicas; Guimarães Rosa: contista; e Frente ao "Espelho" e entre diálogos, uma entrevista com Alaor Barbosa, através da qual o escritor brasiliense apresenta a biografia Sinfonia Minas Gerais: a vida e a literatura de João Guimarães Rosa; e, ainda, uma resenha sobre o filme Mutum, adaptação fílmica da novela Campo Geral.

Temos, ainda, a satisfação de deixar registrado que versões digitalizadas da REVISTA DA ANPOLL estão disponíveis no site da Anpoll (www.anpoll.org.br/revistas), a partir do número 22, uma forma de aumentar significantemente o número de leitores e pesquisadores interessados pelo conteúdo do periódico de nossa associação.

\section{André Luís Gomes}

